\title{
HISTOLOGICAL ASSESSMENT OF GINGER (ZINGIBER OFFICINALE) EXTRACT ON TONGUE DORSAL SURFACE IN DIABETIC RATS
}

\author{
Amira A. R. Moawad* and Sally H Abo Baker*
}

\begin{abstract}
Objective: To investigate anti-diabetic effect of ginger extract in streptozotocin- induced diabetes mellitus in albino rats.

Methodology: 30 adult male albino rats were divided into three groups, 10 rats each: group I: negative control took commercial diet, group II rats were administered a single injection of freshly prepared streptozotocin at a dose of $50 \mathrm{mg} / \mathrm{kg} / \mathrm{b} . \mathrm{w}$, which was dissolved in citrate buffer at PH 4.2 , group III rats were given a single dose of freshly prepared streptozotocin $(50 \mathrm{mg} / \mathrm{kg} / \mathrm{b} . \mathrm{w})$, and after 3 days Ginger aqueous extract was given orally by gastric gavage in a daily dose of $400 \mathrm{mg} / \mathrm{kg}$ body weight of rat for 4 weeks. Tongue was carefully dissected and processed for Haematoxylin \& Eosin, and ki- 67.

Results: histological examination revealed that normal thread like keratinized filliform papillae with equal thickness of the lingual epithelium, the lamina propria and the muscular layer appear with normal architecture in group I. While in group II complete loss of the conical shape filliform papilla occurred, the lamina propria and the muscular layer were markedly accompanied with inflammatory cell infiltration. In group III the filliform papillae began to regain their normal appearance. Immunohistochemical results showed the intense nuclear reaction to ki-67 in group I and III, while in group II the reaction was mild.
\end{abstract}

Conclusion: including ginger in diet can be effective in eliminating the effect of diabetes on tongue papillae.

KEYWORDS: diabetes mellitus, ginger, ki-67.

\section{INTRODUCTION}

The most important function of tongue is food manipulation to enables mastication, teeth cleaning and helping in swallowing and speech, while in animals maintain vocalization. So its importance is considered in the digestive system and it is the main organ of taste in the gustatory system. Its dorsal surface is covered by taste buds present in fungiform, circumvallate and foliate papillae. It is highly innervated and supplied by many blood vessels ${ }^{1}$.

\footnotetext{
* Lecturer of Oral Biology Department, Faculty of Dentistry, Mansoura University, Egypt
} 
Diabetes mellitus is a long lasting disease manifested as elevation in blood glucose level as a result of impaired insulin function or secretion ${ }^{2}$. Control of hyperglycemia in these patients is needed to reduce its complication of micro- and macro vascular disease $^{3-5}$. But the side effects of hyperglycemic agents available in the markets have impeded their usefulness as antidiabetic agents. So continuous effort was made to explore another therapeutic agent which can overcome the deleterious effect of diabetes ${ }^{6,7}$.

Herbal agents have been explored in East Asian countries and approved to provide high percentage of medical remedies in developing countries ${ }^{8}$. Consequently its popularity is increased in western country and gain more importance in people healthcare. One of these beneficial herbal agents is ginger ${ }^{8,9}$.

Ginger's (Zingiber officinale), beneficial effects including anti-bacterial, anti-convulsing, pain relieving, ulcer curing, and anti-fungal ${ }^{8,9}$. It also helps the treatment of cardiovascular diseases due its anti-inflammatory, anti-platelet and hypo-lipidemic effects ${ }^{10}$. Researchers stated that its inorganic part may be responsible for the hypoglycemic activity. Supporting this believe $(\mathrm{Ca}++, \mathrm{Zn++}, \mathrm{K}+$ etc) found in ginger components, are involved in mechanism of insulin release ${ }^{11-13}$.

Ki67 is a protein, involved in the earlier steps of RNA synthesis ${ }^{14}$. It is found in cell nucleus during all phases of cell proliferation, but not in the G0 (cell quiescent state), its expression varies throughout the cell cycle, reaching the highest level during mitosis. So its main role is in cell division and ribosomal RNA synthesis ${ }^{15}$.

\section{MATERIAL AND METHODS}

Thirty white male albino rats, weighting 125$160 \mathrm{gm}$ were used in this study. Rats were kept at constant environmental and nutritional conditions throughout the period of experiment. The animals were left 14 days for acclimatization before the beginning of the experiment.
Experimental protocol was approved by, Faculty of dentistry, University of Mansoura, Egypt.

Experimental design: animals were divided equally into three sets:

I : (control group) rats were fed with commercial diet.

II: rats were administered a single injection of freshly prepared streptozotocin at a dose of $50 \mathrm{mg} / \mathrm{kg} /$ body weight and dissolved in citrate buffer at PH $4.2{ }^{16}$. After $72 \mathrm{~h}$, streptozotocin treated rats were fasted for 12 hours, and blood samples were collected from the tail.

III: rats were given a single injection of freshly prepared streptozotocin at a dose of $50 \mathrm{mg} /$ $\mathrm{kg} /$ body weight after blood sampling Ginger aqueous extract was given orally by gastric gavage in a daily dose of $400 \mathrm{mg} / \mathrm{kg}$ body weight of rat for 4 weeks ${ }^{17}$.

Aqueous ginger infusion was prepared by using $3 \mathrm{~g}$ of ginger powder which was dissolved in 100 $\mathrm{mL}$ hot-distilled water and left until it was used.

Tongue was carefully dissected and processed for Haematoxylin \& Eosin, and ki- 67.

\section{Immunohistochemistry evaluation}

- Sections were immune-stained using avidinbiotin technique. Sections were stained with $\mathrm{Ki}$ 67 (Sigma- Aldrich, St Louis, USA).

\section{RESULT}

\section{Statistical analysis results:}

\section{Histological examination revealed the following:}

Group I: showed normally appeared thread like keratinized filliform papillae with equal thickness of the lingual epithelium. The lamina propria and the muscular layer appear with normal architecture

Group II: showed complete loss of the conical shape of filliform papilla. The lamina propria and the muscular layer were markedly accompanied with inflammatory cell infiltrate 
TABLE (1) showing mean \pm SD for blood glucose level after diabetic induction and its statistical analysis results for the different groups:

\section{Blood glucose}

\begin{tabular}{|c|c|c|c|c|c|c|}
\hline & & \multirow{2}{*}{ Group I } & \multirow{2}{*}{ Group II } & \multirow{2}{*}{ Group III } & \multicolumn{2}{|c|}{ ANOVA } \\
\hline & & & & & F & P value \\
\hline \multirow{2}{*}{ One week } & Mean & $191.67^{\mathrm{A}}$ & 384.25 & $293.33^{\text {А В }}$ & \multirow{2}{*}{20.08} & \multirow{2}{*}{0.000} \\
\hline & SD & 74.70 & 32.74 & 35.02 & & \\
\hline \multirow{2}{*}{ Two weeks } & Mean & $196.17^{\mathrm{A}}$ & $436.38^{\mathrm{a}}$ & $245.83^{\mathrm{A}}$ & \multirow{2}{*}{14.9} & \multirow{2}{*}{0.000} \\
\hline & SD & 150.16 & 42.27 & 33.37 & & \\
\hline \multirow{2}{*}{ Three weeks } & Mean & $193.55^{\mathrm{A}}$ & 466.86 & $212.83^{\text {А В }}$ & \multirow{2}{*}{12.6} & \multirow{2}{*}{0.000} \\
\hline & SD & 90.27 & 45.23 & 30.21 & & \\
\hline \multirow{2}{*}{ Four weeks } & Mean & $197.43^{\mathrm{A}}$ & 487.34 & $196.93^{\mathrm{A}}$ & \multirow{2}{*}{11.2} & \multirow{2}{*}{0.000} \\
\hline & SD & 101.83 & 498.22 & 29.79 & & \\
\hline
\end{tabular}

All results are expressed as mean \pm standard deviation (SD).

Non significant: at $\boldsymbol{P}>0.05$.Significant: at $\boldsymbol{P}<0.05$.

$P$ value represent significance between group I, group II and group III groups in different weeks

A = significance between group II and group I or group III (in all weeks groups)

B = significance between group I and group III (in all weeks groups)

a= significance between week One and Other weeks after it (in all groups group I, group II and group III)

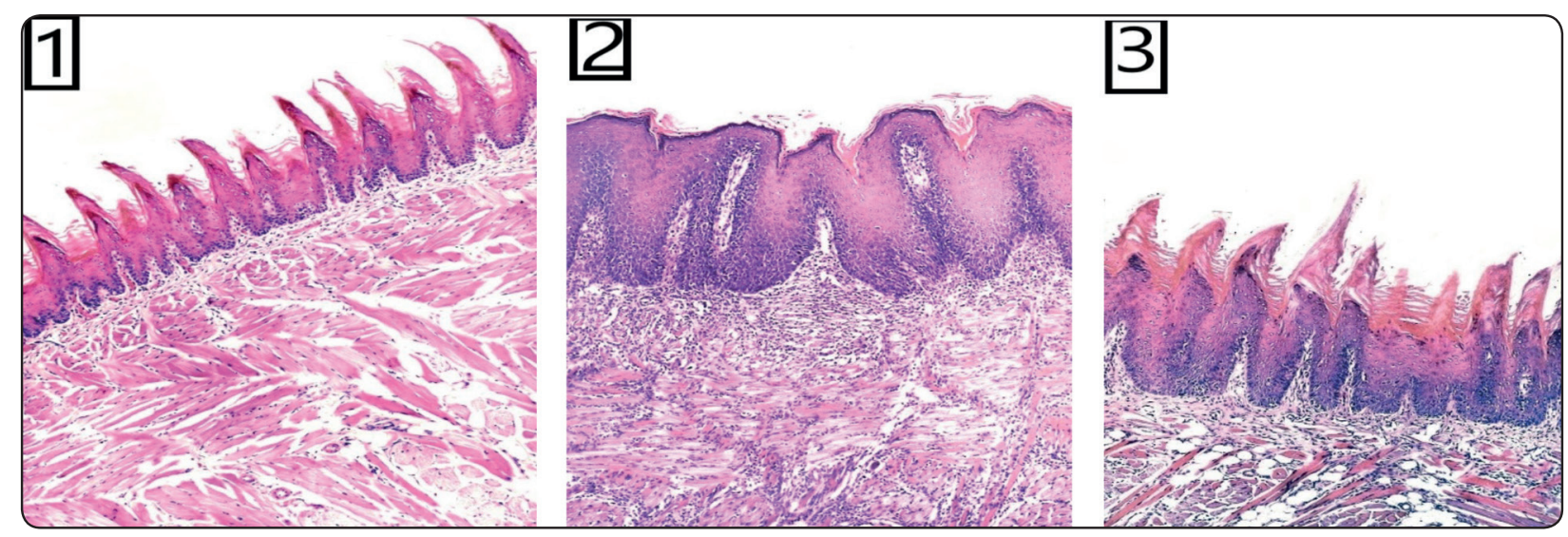

Fig. A: (1) group I showed the normally appeared thread like keratinized filliform papillae with normal architecture of the lamina propria. (2) Group II showed loss of the conical shape of filliform papillae with inflammatory cell infiltrate of the lamina propria. (3) Group III showing the papillae appeared to regain their normal appearance. (H\&E stain x 100). 


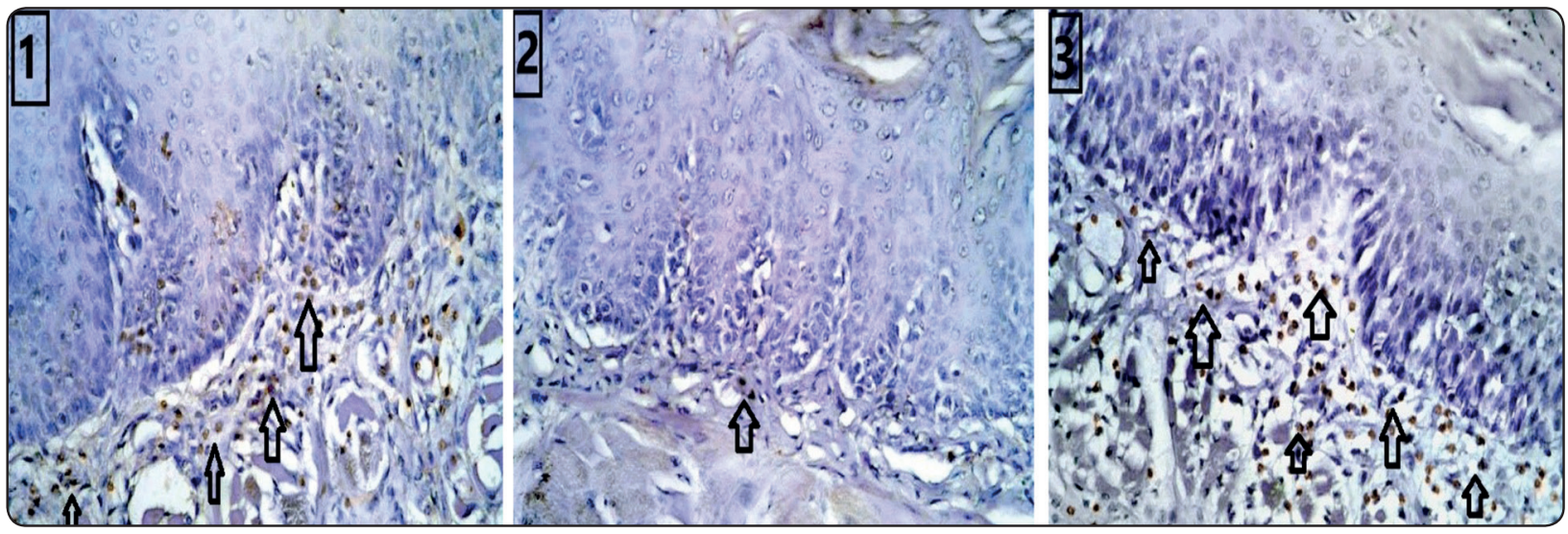

Fig B: (1) group I showing moderate positively immunohistochemical reaction for Ki-67, (2) group II showing decrease in the immunohistochemical reaction for Ki-67, (3) group III showing intense positively immunohistochemical reaction for Ki67. (IHC x 400)

Group III: showed the filliform papillae begin to regain their normal appearance.

\section{Ki- 67 examination:}

In control group I, positively stained proliferative cells were observed in the connective tissue. In group II, the proliferative cells decreased in number when compared to control group. In group III, the proliferative state of the cells was improved, the connective tissue showed more positive cells when compared to group II.

TABLE (2) showing high immunoreactivity in diabetic group compared to control and ginger group

\begin{tabular}{|c|c|c|c|}
\hline & Control & Diabetic & ginger \\
\hline Area \% & $1.49 \pm 0.057$ & $0.55 \pm 0.41^{* * * *}$ & $1.72 \pm 0.37^{* * * \# \#}$ \\
\hline
\end{tabular}

Data expressed as mean \pm SD, P: Probability: significance $<0.05$ Test used: One-way ANOVA followed by post-hoc tukey $* P<0.05 ; * * P<0.01 ; * * * P<0.001$ vs. Control group. $\# P<0.05 ; \# \# P<0.01 ; \# \# \#<0.001$ vs. diabetic group.

\section{DISCUSSION}

In diabetes mellitus it has been documented that atrophic tongue lesions were observed in $26.9 \%$ of patients and $61.7 \%$ of these lesions were central papillary atrophy, and it was likely that vascular damage was the underlying cause of atrophic lesions prior to the diagnosis of diabetes mellitus, ${ }^{18}$.

In the current study the histological examination of the dorsal surface of the tongue in group II showed loss of the conical appearance of the filliform papillae with inflammatory cell infiltration in the lamina propria and muscular layer that comes in coincide with Heba Mohamed Eltokhey, 2013 who found that Examination of the diabetic rat tongues revealed a loss of normal filiform papillae appearance. Most of them showed flattening with obvious hyperkeratosis, loss of their characteristic conical shape, ${ }^{19}$.

(Mamoru UEMURA, et al., 2009) also investigated the connective tissue papillae on the lingual dorsum in the type 2 diabetes mellitus model rats and stated that DM causes regressive change in the connective tissue filiform papillae in (Goto-Kakizaki rats; GK rats). They considered the relationship between the blood glucose level and the fibroblasts as a possible cause of regressive changes in the filiform papillae concluding that high 
concentration of the fasting blood glucose levels inhibit the proliferation of the fibroblasts in the DM group, ${ }^{20}$.

Ginger treatment of diabetic group (group III) showed a significant decrease of serum glucose level, and this come in accordance with Azza H.Abd Elwahab and Faten I. Ali, 2015 who investigated ginger's effect on renal tissues in streptozotocininduced diabetic rats, ${ }^{21}$.

Sultana et al.and Salim (2014) ${ }^{22,23}$ demonstrated that serotonin receptors may be involved in hypoglycemic effect of ginger. Serotonin receptors mediate suppression of insulin release and ginger can antagonize this suppressive effect. Also, Eleazu et al. (2013) ${ }^{24}$ explained hypoglycemic effect of ginger by inhibition of the glycolytic activity of brush border enzymes of the small intestine by polyphenolic compounds of ginger (alkaloids, tannins and flavinoids). Flavinoids such as antioxidants can overcome the deleterious effects of oxidative stress that causes impairment of pancreatic beta cell function due to, thus decreasing hyperglycemic effect of diabetes.

The activity of Ki-67 was markedly lower in the streptozotocin-induced diabetic rats compared with the control group and this was in accordance with Turan KARACA, et al., 2015 who searched for the protective effects of royal jelly against testicular damage in streptozotocin-induced diabetic rats and stated that diabetes produces increase in oxidative stresses, thus elevation in the number of caspase- 3 positive cells occur, producing continuing oxidative disturbance, ${ }^{25}$.

Supporting our results (Joy Jackson-Guilford, et al., 2000) proved that Streptozotocin-induced diabetes produced a dramatic decrease in cell proliferation in the dentate gyrus as compared to controls, when they measured the number of 5-bromo-2'-deoxyuridine (BrdU)-positive cells, an indicator of cell proliferation, in the dentate gyrus in an animal model of diabetes, ${ }^{26}$.
Yiming Li, et al., 2012 explain another mechanism of ginger to overcome the diabetic effect of STZ, as ginger causes inhibition of key enzymes which control carbohydrate metabolism and increased insulin release/sensitivity, providing better glucose uptake in peripheral adipose and skeletal muscle tissues. Ginger also decrease lipid that is also improving the insulin resistant condition, ${ }^{27}$.

\section{CONCLUSION}

Ginger have positive results in eliminating DM and should be included in the food of diabetic individuals. More investigation is needed to know which components in ginger contribute to these effects.

\section{REFERENCES}

1. Maton, Anthea; Hopkins, Jean; McLaughlin, Charles William; Johnson, Susan; Warner, Maryanna Quon; LaHart, David; Wright, Jill D. Human Biology and Health. Englewood Cliffs, New Jersey, USA: Prentice Hall. ISBN 0-13981176-1, 1993.

2. Mustafa SS, Eid NI, Jafri S, El-Latif HAA, Ahmed HM. Insulinotropic effect of aqueous ginger extract and aqueous garlic extract on the isolated perfused pancreas of streptozotocin induced diabetic rats. Pakistan J Zool;39(5):279-284, 2007.

3. K. K. Ray, S. R. K. Seshasai, S. Wijesuriya et al., "Effect of intensive control of glucose on cardiovascular outcomes and death in patients with diabetes mellitus: a metaanalysis of randomised controlled trials," The Lancet, vol. 373, no. 9677, pp. 1765-1772, 2009.

4. R. R. Holman, S. K. Paul, M. A. Bethel, D. R. Matthews, and H. A. W. Neil, "10-Year follow-up of intensive glucose control in type 2 diabetes," The New England Journal of Medicine, vol. 359, no. 15, pp. 1577-1589, 2008.

5. F. Ismail-Beigi, T. Craven, M. A. Banerji et al., "Effect of intensive treatment of hyperglycaemia on microvascular outcomes in type 2 diabetes: an analysis of the ACCORD randomized trial," The Lancet,vol.376,no.9739, pp.419-430, 2010.

6. B. White, "Ginger: an overview," American Family Physician, vol. 75, no. 11, pp. 1689-1691, 2007. 
7. W. H. Wang and Z. M. Wang, "Studies of commonly used traditional medicine-ginger," Zhongguo Zhongyao Zazhi, vol. 30, no. 20, pp. 1569-1573, 2005.

8. Ahmed RS, Sharma SB. Biological studies on combined effects of garlic (Allium sativum Linn.) and ginger (Zingiber officinale Roscoe.) in albino rats. J Exp Biol; 35 : 841-3, 1997.

9. Kikuzaki H, Nakatani N. Antioxidant effects of ginger constituents. J Food Sci; 58: 1407-10, 1993.

10. Nicoll R, Henein MY. Ginger (Zingiber officinale Roscoe): a hot remedy for cardiovascular disease? Int J Cardiol; 131(3): 408-9, 2009.

11. Marles RJ, Farnsworth NR. Antidiabetic plants and their active constituents. Phytomedicine; 2(2): 137-89, 1995.

12. Ajit K, Choudhary BK, Bandhopadhyay NG. Preliminary studies on the inorganic constituents of some indigenous hypoglycemic herbs on oral glucose tolerance test. J Ethnopharmacol; 64: 179-84, 1999.

13. Sharma M, Shukla S. Hypoglycaemic effect of ginger. J Res Ind Med Yoga Homoeopathy; 12: 127-30, 1977.

14. Gerdes J, Schwab U, Lemke H, Stein H. Production of a mouse monoclonal antibody reactive with a human nuclear antigen associated with cell proliferation. Int $\mathrm{J}$ Cancer 1983; 31: 13-20.

15. Lee LH, Yang H, Bigras G. Current breast cancer proliferative markers correlate variably based on decoupled duration of cell cycle phases. Sci Rep 2014; 4: 5122.

16. Ramanthan, M., Kaiswal, A.K., Bhattathacharya, Y.S. K. Superoxide dismutase catalase \& glutathrone peroxidase activity in the brain of STZ induced diabetes in rats Indian J. Axp. Biol., 37:182-183, 1999.

17. Elrokh, E., Yassin, N.A., El-Shenawy, S.M., Ibrahim, B.M. Antihypercholesterolaemic effect of ginger rhizome (Zingiber officinale) in rats: Inflammopharmacology. 18(6): 309-15, 2010.

18. Farman AG. Atrophic lesions of the tongue: A prevalence study among 175 diabetic patients. J Oral Pathol; 5:255264, 1976.
19. Heba Mohamed Eltokhey.2013. The Influence Of Ozonized olive oil gel on the dorsal surface of the tongue ofstreptozotocin induced diabetic albino rats. J Am Sci;9(10):193-201, 2013.

20. Mamoru UEMURA, Yoshitaka TAMADA and Fumihiko SUWA. Morphological Study of the Connective Tissue Papillae and the Capillary Loops on the Lingual Dorsum in the Type 2 Diabetes Mellitus Model Rats. Okajimas Folia Anat. Jpn., 85(4):139-149, February, 2009.

21. Azza H. Abd Elwahab and Faten I. Ali. Mitigation of alloxane - induced renal damage by zingeber officinal (ginger) root in rats: an impact on oxidative stress, inflammatory cytokines and tissue damage. Al-azhar assiut medical journal vol 13, no 1 , January 2015 suppl-1.

22. Sultana, S.; Khan, M.I.; Rahman, H.; Nurunnabi, A.S.M. and Afroz, R.D. Effects of ginger juice on blood glucose in alloxan induced diabetes mellitus in rats. J Dhaka Med Coll, 23(1):14-17, 2014.

23. Salim, K.S. Hypoglycemic property of ginger and green tea and their possible mechanisms in diabetes mellitus. The Open Confer Proceed J, 5: 13-19, 2014.

24. Eleazu, C. O.; Iroaganachi, M.; Okafor, P. N.; Ijeh, I. I. and Eleazu, K. C. Ameliorative potentials of ginger (Z. officinale Roscoe) on relative organ weights in streptozotocin induced diabetic rats. Int J Biomed Sci, 9(2): 82-90, 2013.

25. Turan KARACA, Selim DEMIRTAŞ, İhsan KARABOĞA, Süleyman AYVAZ. Protective effects of royal jelly against testicular damage in streptozotocin-induced diabetic rats. Turk J Med Sci 45: 27-32, 2015.

26. Joy Jackson-Guilford, J. David Leander and Laura K. Nisenbaum. The effect of streptozotocin-induced diabetes on cell proliferation in the rat dentate gyrus. Volume 293, issue 2, 27 october 2000 .

27. Yiming Li, Van H. Tran, Colin C. Duke, and Basil D. Roufogalis. Preventive and Protective Properties of Zingiber officinale (Ginger) in Diabetes Mellitus, Diabetic Complications, and Associated Lipid and Other Metabolic Disorders: A Brief Review, doi:10.1155/2012/516870, 2012. 